\title{
Different Concepts of Values in Chinese and Western Movies
}

\author{
Xiaoxi WANG \\ English Department of Applied Technology School, University of Science and Technology Liaoning, Anshan, Liaoning, China \\ 85067435@qq.com
}

\begin{abstract}
As a synthetic art, movie integrates our multifarious real life into a short but essential section. People will see a certain subject of narrative art in film, which can be said that film is a window for looking at the world. We can see that the differences in culture and views are in every aspect of life, which have formed a sign of diversification. Therefore, it becomes quite important for us people to deal with the differences well. During the process, there are inevitably maladies of formalization, but more and more people will pay attention to the characters of various cultures and their future.

Index Terms - eastern, western, values, concepts
\end{abstract}

\section{Introduction}

A.As a synthetic art, movie integrates our multifarious real life into a short but essential section.

The great invention was called by Brother Lumiere "cinema", which means "recording down the moves". "Cinema" was brought out after the appearing of broadcast but before the appearing of TV. "It stands for the most important cultural progress during early 20 th century. Film is such a kind of art and a way of communication that embodied the mystery of this period. People will see a certain subject of narrative art in film, which can be said that film is a window for looking at the world. It covers many aspects such as economy, science, society, art, etc.

\section{B. Movie is bound to our life and the society, reflecting them and being reflected by them.}

There are a lot of interesting sayings of "film": "Film erases art, surpass art, and sublimes art. Film brings hope for the sup-realists. Film gives us life. It is the effectual medicine for literature and gives literature fresh blood. Film' abstract function attracts us. Film makes the power of images to take the place of the world's power. By some certain things, cinema makes a kind of relative internal language, which embodies itself in its name and the way that should be in people's mind." (Litman 132) On the contrary, the language was influenced by the way of communication. Obviously, behind the images or in the pictures, a kind of language is trying to let the audience understand it. At the same time, the colliding among the words gives birth to some meaning.

People watch movies, enjoying the fun, beauty, sadness, excitement, or horror. Moreover, at the same time, we feel the different tastes in the views of value. When we watch a French movie, we can feel the romance of the French style; when you watch a Indian movie, we will have a full sight of the Indian dance, feathers, and furs; when we see a Korean movie, we can smell the aroma of the Korean cooking; when we see a
Chinese costume movie, we will be influenced right now by the mystery of Chinese kungfu. We can say that, movie itself is a kind of culture, which unconsciously reflects a big culture behind it. That varies from time to time, from society to society, from area to area, from country to country.

\section{Main Body}

Movie is not only a kind of entertainment, but also reflects real life for us. In my opinion, eastern and western movies both contain a great deal of cultural and social information which is worth deciphering and studying carefully. Movie is a way of active reflection of its cultural society, a kind of deposition of history, and a special method of annotation to the points of value and life. Some modern socialists consider that, the system of value determines the cultural psychology of the society. Value consciousness imposes crucial influence upon the human's behaviors, and then upon the whole cultural modality---including the profound impact in economy and politics.

A. The Chinese "Benevolence" v.s. the western "Caritas".

(1) Chinese "virtue" generally refers to "love", "fealty", "obedience", etc.

"Benevolence" ideology is of profound humanity and social conception. It firstly is based on emphasizing and respecting man's position. Mencius believed that the essential difference between animals and humans is human's "ethic", which means man's sociality. "Benevolence" ideology emphasizes the positive side of the human nature, which is the mental fountain created by morality. "Benevolence" ideology can be considered the basic principle to maintain the relationship among people in the society of civilization. Its inchoate form comes from the basic ethic "filial piety", which is called "being kind to the relatives is kind". "Benevolence" ideology requires people to love the relatives first, and only when this kind of affection comes true, the love to others can come true too, and then "Benevolence" comes true. "Benevolence" ideology has been the supreme principle of Chinese cultural life. In the days when too many are the local wars and conflicts between country and country, nation and nation, religion and religion, more and more men of insight advocate the "Benevolence" ideology as the global universal ethic, as the solution to deal with the problems in the world, as the common base to set up the rules of human world. "Benevolence" ideology provides us harmony to realize the ideal peace. 
However, "Benevolence" ideology also has its abuse. Since "Benevolence" ideology is founded on the base of "ethic", usually to judge things is not from principles or justice, but from ethic or feelings. People are always afraid of offending their intimates. In this way, people are generally lack of the consciousness of law and democracy. They tend to wave the flag of feelings instead of the laws, so that since long time ago the authority has been more powerful than the laws in our society, which social problem is quite hard to solve.

(2)"Caritas" generated from the principle of Christians, meaning "to love the whole world".

"Caritas", which means "the universal love to the human beings," was advanced as the slogan in the French Bourgeois Reform in 18th century. The westerners believe that, "love" was engendered from nature instinct, not only for the human beings, but also for the birds in the sky, the fish in the sea, and the beasts in the desert. "Love" dominates everything on earth equally, which also can be seen as a definition to "caritas". The westerners believe the power of love, that love is able to conquer everything and to destroy everything, because love has two sides of virtue and evil. "Love" is without fail the seed of your virtue and without fail the seed of your evil. We can see that, the western "caritas" is set up on the understanding to human nature. They believe, "kindness" is the God, and "evil" is the devil. If you want to erase the half of evil and to perfect the half of kindness, you should trust the God, love the God, love the truth, and love the people all over the world, including your friends, your neighbors, and even your foes.

"Christian theology deems God creates and love all the human beings, and the supreme love of human is that to God. The love behaves as a kind of 'mercy' and 'benignity', for which people should condemn or reject self-love and life of flesh and blood." (Chen 124) Though the sanctified caritas was impacted, it still influences a lot on the European conception about love. "Caritas" which was advanced as the slogan in the French Bourgeois Reform in 18th century embodied the liberation of human nature from "deity". "Caritas" set up on "human nature", so the westerners do not think "evil" should be eliminated, but contain it as the bone of the bone and fresh in their culture to "combat poison with poison". "Caritas", not like "benevolence" depending on its self-struggling, but depends on "evil" to produce power for itself.

B.The Chinese "Collectivism" v.s. the western "Individualism" (1) The Chinese movie, "Kong Fansen", which reflected the Chinese "collectivism", which means "country or nation centered".

Collectivism is an essential value tropism of Chinese traditional ethic. The philosophical conception of which the nature and human unite as one takes the idea that man is one part of the nature, one's life is fatality, and man's doctrine is also the nature's doctrine. Ethic, affection, and fate make an individual one knot on the net, and the value of individuals can come true only when the value of colony comes true. In Chinese mind, "kin" is the most important relationship among so many sorts of social relationships. Individual is just one numerator dependent on it, without "individual" space.
Chinese are used calling one person as one part but not an individual. That is decided by the need of collective surviving, so everyone is the derivative from the relationships that he affiliates with. Individuals are meaningful only when they are put into the proper social relationships. From ancient time till now, this tropism of value has been leading the Chinese to think more of the interests of the nation, of the country, and of the society, which ideology is already deep in people's mind. The spirit of cohesion, justice, resolution, and selflessness all come into being from it.

Individual creativity cannot be fully taken into play. In addition, collectivism cannot make individual to play an important role in dealing with public behaviors, especially when this behavior concerning with others. It is apt to authority, but not democracy. This kind of effects can be seen obviously during the time of the Culture Revolution. China lost two significant chances to develop together with those advanced countries: one is in the period of Ming and Qing, the other is in 1950 s to 1970 s, which really have something to do with the oppressing of collectivism.

\section{(2) "Individualism" focuses on the individual development.}

The trend of point of value in western ethic is "Individualism". As early as the 6th century BC, the democracy system in Athens emphasized the individual effects as well as the interests of city-state. The western producing style was mainly navigation in industry and commerce, which decided that this kind of producing style cold not keep the assembling living for long. The relationships among people were not based on consanguinity, but mainly on the law regulated by the political system of the government. The western culture put human being at the place opposite to the nature. According to the culture, individual always kept it independent from others, and individual value's coming true was at the first place.

This tropism of value was the westerners' “individualism", especially projecting after the Renaissance. It help mold the personality of independence, which is good at expressing, seeking truths with simplicity and honesty. "Individualism" isolates people from each other. Besides, it brings together with the material desire, enjoyments, money worship, not only over the western society, but also all over the world, and extremely misleads the young.

C. The Chinese "Obligation" v.s. the western "Right".

(1) Chinese virtue emphasizes one's responsibilities to the society or the nation.

"Everyone can be Yao Shun" just means excel in morality, rather than the right to administration. The feudal governors command the common people to be indifferent to fame and wealth, to give up the pursuit toward rights, and to do the duty as required. Chinese consciousness of obligation, not only for the ethical duty, but also for realizing the value of life, is a high bourn in life. With strong moral dream, it embodies the recognition and respect to spiritual culture, as well as the sublimity of morality. It lays the centre on benevolence, so it tend to mislead people to blindly control their desire but emphasize their obligation in order to deal with 
the relationships among people. That well reflects the situation as "obligation-obligation", not as "right-obligation".

About obligation, Sun Zhongshan said like this, nowadays, how to apply the name of freedom? Do not to individuals, just to countries; otherwise, there would be a parcel of sand. Individuals should not be given too much freedom, but countries can be. If it got complete freedom, China would become a strong one. In order to this goal, the people's freedom is maybe to be deprived.

(2) The West usually emphasizes one's rights as a man.

The western "duty", different from Chinese, contains definitude sense of "right-obligation", and the concept of "right" has been greatly regarded in European history, except for the Christians. According to the natural law, every man burns equal. Human's free right was considered to be endowed with by nature. After the Renaissance, the right consciousness was projecting. Foltie told people, that obedience is the real unhappiness. In his mind, men are all equal, and everyone has the right to do the things that are absolutely commanded in his will. Before the time of Foltie we just see the names of the chief of the country; Foltie surpassed the chief of the country, and he was the chief of thought. During the hundreds of years since that on, the individual right of capitalism has greatly release the maximum potential and creativity of people.

The westerners think that, the common practice of law will endow everybody with equal rights, which is helpful to the form of society. While Chinese consciousness of duty was usually tied to "obligation", so it was implemented by "courtesy". Although everyone had a wish of behaving with benevolence and kindness, on the contrary, there were indeed many sanctimonious dissemblers. Owing to the unbalance between morality and law, it was impossible for individual rights to come true. Therefore, without the protection of laws, the individual rights are just like the castle in the air.

\section{Conclusion}

A. How we should look on the differences of cultures:

Culture collision is an inevitable phenomenon in the space of culture, and it will bring serious impacts. Therefore, as a developing country, if China needs to maintain its peaceful and steady development, what should be done to suit the culture collision well, erase the bad impact, so that China can get further progress?

Chinese culture being one of the main cultures in the world, it come to the first place how to exist and develop in the collision. We see that, the $21 \mathrm{st}$ century culture must be multiplied. Culture comes out during the activities of producing goods. Humans live in different geographical environments, so different are their cultures. In order to keep its culture's vigor, China should establish the tree of the culture in the soil of its own nation. Some elements in the traditional culture will not only avoid or reduce the culture collision, but also be in concert with the modern culture of substance and spirit. We should treat all the cultures fairly with respect and appreciation. While studying the western advanced culture and creating new culture, we at first keep our own nation's features, endeavor to bring the profundity of cultural accumulations into play. At the same time, we can improve our education to open our mind and to accept or learn the different cultures in an advanced way.

B. Arts, such as movies, paintings, literary, cannot be parted from the culture, which is diversified. Therefore, a healthy culture will help art progress; on the contrary, art's progress will foster the global culture's development.

From silent to phonic, from monochrome to colored, from several-minute long to over- one-hour long, movie had a long history in its development. Arts, such as movies, paintings, literary, also have the same experience with movies, and cannot be parted from the culture. Therefore, we can see that, a healthy culture will help art progress; on the contrary, art's progress will foster the global culture's development without fail.

It should be mentioned here that diversification brings abundance of material and culture, and creates better condition for the development of material culture and spiritual culture. During the process, there are inevitably maladies of formalization, but more and more people will pay attention to the characters of various cultures and their future.

\section{References:}

[1] DeFleur, Melvin.L. Milestones In Mass Communication Research Beijing: People University Press 2004

[2] Litman, Barry. R. The Motion Picture Mega-Industry Tsinghua University Press 2005 